\title{
PENGARUH PENEMPATAN KARYAWAN TERHADAP KINERJA KARYAWAN MELALUI MOTIVASI PADA PT BANK MUAMALAT INDONESIA, TBK CABANG JEMBER
}

\author{
Safrina Hafifatur Rochmah \\ Fakultas Ekonomi dan Bisnis, Universitas Jember \\ safrinahafifaturrochmah@gmail.com
}

\begin{abstract}
This study aimed to analyze the dimensions of the employee work placement (promotion, transfer, and demotion) on motivation and employee performance, and to analyze the effect of motivation on employee performance. The sample consisted of 39 (thirty nine) respondents. Data were analyzed using path analysis. Results show that the total effect of the promotion variable on motivation is 0.618 or $61.8 \%$. The total effect of the mutation on motivation is 0.003 or $0.3 \%$. The total effect of demotion variable on motivation is 0.125 or $12.5 \%$. The total effect of the promotion variable on employee performance is 0.687 or $68.7 \%$. The total effect of mutation on employee performance is 0.012 or $1.2 \%$, the total effect of demotion variable on employee performance is 0.038 or $-3.8 \%$, and the total effect of motivation variable on employee performance is 0.685 or $68.5 \%$.
\end{abstract}

Keywords: Promotion, Transfer, Demotion, Motivation, and Employee Performance.

\begin{abstract}
Abstrak:Penelitian ini bertujuan untuk menganalisis pengaruh dimensi penempatan karyawan (promosi, mutasi, demosi) pada motivasi dan kinerja karyawan, serta pengaruh motivasi pada kinerja karyawan. Sampel penelitian terdiri dari 39(tiga puluh sembilan) karyawan sebagai responden. Data dianalisis dengan menggunakan analisis jalur. Hasil penelitian menunjukkan bahwa pengaruh variabel promosi terhadap motivasi adalah sebesar 0,618 atau $61,8,5 \%$. Total pengaruh mutasi terhadap motivasi adalah sebesar 0,003 atau $0,3 \%$. Total pengaruh variabel demosi terhadap motivasiadalah sebesar $-0,125$ atau $-12,5 \%$. Total pengaruh variabel promosi terhadap kinerja karyawan adalah sebesar 0,687 atau $68,7 \%$. Total pengaruh variabel mutasi terhadap kinerja karyawan adalah sebesar 0,012 atau $1,2 \%$. Total pengaruh variabel demosi terhadap kinerja karyawanadalah sebesar -0,038 atau $3,8 \%$ dan total pengaruh variabel motivasi terhadap kinerja karyawan adalah sebesar 0,685 atau $68,5 \%$.
\end{abstract}

Kata Kunci: Promosi, Transfer, Demosi, Motivasi, dan Kinerja Karyawan.

\section{Pendahuluan}

Kondisi perekonomian di Indonesia yang dinamis menuntut Industri perbankan di Indonesia dituntut untuk tanggap terhadap perubahan ekonomi yang dapat terjadi sewaktuwaktu. Perusahaan harus selalu kreatif dan berinovasi dalam unit bisnis dan operasi. Kelangsungan suatu organisasi sangat dipengaruhi oleh berbagai aspek manajemen, salah satunya aspek sumber daya manusia yang ada, baik kualitas maupun kuantitasnya. Manajemen sumber daya manusia harus dapat memanfaatkan SDM sesuai dengan 
kebutuhan organisasi dan menjalankan fungsinya secara profesional dalam pengambilan kebijakan. Salah satu fungsi penting manajemen SDM yaitu menentukan strategi motivasi untuk menghadapi kondisi kerja karyawan yang bermacam-macam untuk mengatur kelangsungan dan mencapai kemajuan suatu perusahaan.

Salah satu bentuk pemberian motivasi karyawan adalah dengan bentuk penempatan karyawan (Hasibuan, 2002). Penempatan karyawan untuk karyawan lama dan karyawan baru. Pada pembahasan ini ruang lingkupnya adalah penempatan untuk karyawan lama atau karyawan yang sudah bekerja lebih dari satu tahun. Tujuan penempatan karyawan lama pada suatu pekerjaan baru menjadi sangat penting dilakukan yaitu untuk sistem penyegaran dan menempatkan karyawan pada posisi yang tepat sesuai dengan kemampuannya. Konsep penempatan karyawan mencangkup promosi, mutasi, dan demosi.

Promosi menurut Siagian (1991:169) promosi ialah apabila seorang pegawai dipindahkan dari suatu pekerjaan ke pekerjaan lain yang tanggung jawabnya lebih besar, tingkatanya dalam hierarki jabatan lebih tinggi dan penghasilannya pun besar pula. Program ini diberikan sebagai bentuk penghargaan kepada seorang karyawan yang telah menjalankan tugasnya dengan baik, sehingga merasa dihargai dan termotivasi untuk meningkatkan kinerja yang lebih tinggi. Konsep kedua yaitu mutasi,menurut Siagian (1991:171) ada dua bentuk, bentuk yang pertama adalah penempatan seseorang pada tugas baru dengan tanggung jawab, hierarki jabatan dan penghasilan yang relatif sama dengan statusnya yang lama. Yang kedua adalah alih tempat, yang berarti seorang pekerja melakukan pekerjaan yang sama atau sejenis, penghasilan tidak berubah dan tanggung jawabnya pun relatif sama, program ini sangat penting karena bertujuan untuk sistem penyegaran dan menempatkan karyawan pada posisi yang tepat sesuai dengan kemampuannya. Konsep ketiga dari penempatan karyawan adalah demosi, menurut Siagian (1991:171) demosi berarti bahwa seseorang, karena berbagai pertimbangan, mengalami penurunan pangkat atau jabatan dan penghasilan serta tanggung jawab yang semakin kecil. Tujuan demosi yaitu memberikan motivasi negatif kepada karyawan karena mengalami penurunan kinerja karena faktor-faktor internal maupun eksternal.

Bank Mumalat Indonesia, Tbk adalah perusahaan perbankan pertama yang mengusung konsep syariah. Perusahaan memiliki beberapa kantor cabang, kantor kas, dan kantor cabang pembantu disetiap wilayah Indonesia, hal ini dimaksudkan agar layanan perbankan dapat mudah dijangkau oleh masyarakat. Salah satu cabang Bank Mumalat Indonesia, Tbk yakni di wilayah kabupaten Jember, Kantor Cabang Jember membawahi beberapa kantor cabang pembantu dan kantor kas diantaranya di kabupaten Bondowoso, Situbondo, Banyuwangi, dan Genteng. Penempatan karyawan dilakukan HRD cabang Jember berupa promosi, mutasi, dan demosi. Terjadinya perpindahan penempatan 
karyawan di Bank Muamalat, Tbk cabang Jember dilatarbelakangi oleh banyak hal. Secara umum penempatan karyawan lama pada jabatan yang baru dilakukan untuk memenuhi kebutuhan dan memotivasi karyawan sehingga dapat meningkatkan kinerja, dengan kelebihan ketrampilan dan mengurangi kejenuhan karyawan yang mungkin terjadi. Promosi sering dilakukan karena beberapa hal, antara lain karena prestasi kerja dan senioritas. Mutasi dilakukan melihat faktor jarak tempuh karyawan dari tempat tinggalnya ke kantor terlalu jauh, kebutuhan akan tenaga tambahan, harapan untuk memperoleh ketrampilan yang lebih dibandingkan sebelumnya, serta untuk menurangi tingkat kebosanan karyawan yang mungkin terjadi. Sedangkan demosi dilakukan kepada karyawan melihat dari faktor penilaian negatif oleh atasan, karena prestasi kerja yang tidak atau kurang memuaskan, dan perilaku pegawai yang disfungsional. Penurunan ini jabatan ini jarang terjadi, mengingat dampak negatifnya terhadap moral karyawan suatu organisasi.

Berdasarkan latar belakang yang dijabarkan, penulis ingin menganalisis apakah pengaruh penempatan karyawan dapat mempengaruhi motivasi karyawan sehingga berpengaruh terhadap kinerja karyawan pada Bank Muamalat, Tbk cabang Jember. Oleh karena itu, penulis bermaksud melakukan penelitian dengan judul "Pengaruh Penempatan Karyawan terhadap Kinerja Karyawan melalui Motivasi pada Bank Muamalat, Tbk Cabang Jember".

\section{Metodologi}

Penelitian ini menggunakan jenis penelitian (explanatorry research) dengan pendekatan kuantitatif. Populasi penelitian ini adalah seluruh karyawan banking staff pada Bank Muamalat cabang Jember yang berjumlah 32 orang. Sampel yang digunakan dalam penelitian ini adalah keseluruhan karyawan banking staf pada Bank Muamalat cabang Jember yang berjumlah 32 orang.

Data yang digunakan dalam penelitian ini adalah data primer berupa kuisioner, wawancara dan observasi. Data sekunder dalam penelitian ini meliputi arsip yang tersedia pada Bank Muamlat cabang Jember, laporan penelitian, literatur, dan jurnal penelitian terkait dengan judul penelitian ini meliputi promosi, mutasi, demosi, motivasi, dan kinerja karyawan.

Pada penelitian ini yang menjadi variabel endogen $(X)$, Variabel Penghubung $(Z)$, dan variabel eksogen $(Y)$ antara lain :

1) Promosi $\left(X_{1}\right)$, dengan indikator memperoleh tanggung jawabnya lebih besar dari tanggung jawab sebelumnya $\left(\mathrm{X}_{1.1}\right)$,memperoleh kenaikan jabatan dari jabatan sebelumnya $\left(X_{1.2}\right)$,memperoleh penghasilan atau gaji lebih besar dari jabatan sebelumnya $\left(X_{1.3}\right)$

2) Mutasi $\left(X_{2}\right)$, dengan indikator memperoleh tugas yang baru dengan tanggung jawab yang sama dengan yang sebelumnya $\left(X_{2.1}\right)$,memperoleh jabatan yang relatif sama 
dengan jabatan sebelumnya $\left(X_{2.2}\right)$,memperoleh gaji atau penghasilan yang relatif sama dengan sebelumnya $\left(\mathrm{X}_{2.3}\right)$,perpindahan lokasi tempat yang berbeda dengan sebelumnya $\left(\mathrm{X}_{2.4}\right)$.

3) Demosi $\left(X_{3}\right)$, dengan indikator mengalami penurunan pangkat atau jabatan dari sebelumnya $\left(X_{3.1}\right)$,memperoleh penghasilan yang lebih kecil dari sebelumnya $\left(X_{3.2}\right)$,memperoleh tanggung jawab yang semakin kecil dari tugas sebelumnya $\left(X_{3.3}\right)$

4) Motivasi (Z), dengan indikator kedisiplinan kerja dengan empat indikator yaitu: kesesuaian peraturan perusahaan, penggunaan seragam, ketepatan jam kerja, dan pemenuhan perintah atasan $\left(Z_{1.1}\right)$, keputusan kerja (Work Decision) meliputi keputusan bersama-sama dan keputusan atasan $\left(Z_{1.2}\right)$, tanggung jawab (Responsible) meliputi tanggung jawab individu dan tanggung jawab atasan $\left(Z_{1.3}\right)$, kegairahan kerja meliputi kesenangan bekerja, keluhan kerja, inisiatif dan pekerjaan diluar jam kerja $\left(Z_{1.4}\right)$.

5) Kinerja Karyawan $(Y)$ dengan indikator kualitas $\left(Y_{1.1}\right)$ kuantitas $\left(Y_{1.2}\right)$, ketepatan waktu $\left(Y_{1.3}\right)$, efisiensi biaya $\left(Y_{1.4}\right)$.

Skala pengukuran data pada penelitian ini menggunakan skala Likert dengan dengan lima tingkat preferensi jawaban dengan skor masing-masing 1-5. Model analisis jalur (path analysis) yang digunakan dalam penelitian ini dapat diuraikan dalam persamaan struktural sebagai berikut :

$Z=\beta X_{1 i} Z_{i}+\beta X_{2 i} Z_{i}+\beta X_{3 i} Z_{i}+\varepsilon_{1 i}($ persamaan 1)

$Y=\beta X_{1 i} Y_{i}+\beta X_{2 i} Y_{i}+\beta X_{3 i} Y_{i}+\beta Z_{i} Y_{i}+\varepsilon_{2 i}$ (persamaan 2)

Dimana: $X_{1}=$ Promosi $_{2}=$ Mutasi $_{3}=$ DemosiZ $=$ Motivasi

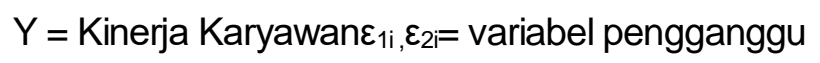

\section{Hasil dan Pembahasan}

\section{$\underline{\text { Uji Hipotesis }}$}

Untuk menguji taraf signifikansi dari hipotesis yang telah diterapkan, maka penelitian ini menggunakan pengujian hipotesis yakni uji t pada alpha $=0,05$ atau $p$-value $<0,05$ sebagai taraf signifikansi dari pengaruh langsung variabel-variabel bebas terhadap variabel tergantungnya.

1) H1(Pengaruh Promosi $\left(X_{1}\right)$ terhadap Motivasi $(Z)$ )

Dari hasil analisis jalur diperoleh nilai diperoleh nilai beta $(\beta)$ sebesar 0,618 dengan $p$-value sebesar 0,002 . Karena nilai $p$-value lebih kecil daripada 0,05 atau $\alpha(0,002$ $<0,05)$ maka $\mathrm{H}_{0}$ ditolak. Dengan demikian dapat diambil kesimpulan bahwa promosi mempunyai pengaruh yang positif dan signifikan terhadap kinerja karyawan Bank Muamalat Indonesia, cabang Jember.

2) H2(Pengaruh Variabel Mutasi $\left(\mathrm{X}_{2}\right)$ terhadap Motivasi $(\mathrm{Z})$ ) 
Berdasarkan tabel (uji Analisis Jalur) dapat dilihat untuk pengujian variabel mutasi terhadap motivasi diperoleh nilai beta $(\beta)$ sebesar 0,003 dengan $p$-value sebesar 0,989 . Karena nilai $p$-value lebih besardari pada 0,05 atau $\alpha(0,989>0,05){\text { maka } \mathrm{H}_{0}}$ diterima. Dengan demikian dapat diambil kesimpulan bahwa mutasi mempunyai pengaruh yang negatif dan tidak signifikan terhadap motivasi karyawan Bank Muamalat cabang Jember.

3) H3(Pengaruh Variabel Demosi $\left(X_{3}\right)$ terhadap Motivasi $(Z)$ )

Berdasarkan tabel (uji Analisis Jalur) dapat dilihat untuk pengujian variabel demosi terhadap motivasi diperoleh nilai beta $(\beta)$ sebesar $-0,026$ dengan $p$-value sebesar 0,902 . Karena nilai $p$-value lebih besar dari pada 0,05 atau $\alpha(0,902>0,05){\text { maka } \mathrm{H}_{0}}$ diterima. Dengan demikian dapat diambil kesimpulan bahwa demosi mempunyai pengaruh yang negatif dan tidak signifikan terhadap motivasi karyawan Bank Muamalt Indonesia, Tbk cabang Jember.

4) H4(Pengaruh Variabel Promosi $\left(X_{1}\right)$ Terhadap Kinerja Karyawan $(Y)$ )

Berdasarkan tabel (uji Analisis Jalur) dapat dilihat untuk pengujian variabel promosi terhadap kinerja karyawan diperoleh nilai beta $(\beta)$ sebesar 0,687 dengan $p$-value sebesar 0,000 . Karena nilai $p$-value lebih kecil dari pada 0,05 atau $\alpha(0,000<0,05)$ maka $\mathrm{H}_{0}$ ditolak. Dengan demikian dapat diambil kesimpulan bahwa promosi mempunyai pengaruh yang positif dan signifikan terhadap kinerja karyawan Bank Mumalat Indonesia, Tbk cabang Jember.

5) H5(Pengaruh Variabel Mutasi $\left(X_{2}\right)$ Terhadap Kinerja Karyawan $(Y)$ )

Berdasarkan tabel (uji Analisis Jalur) dapat dilihat untuk pengujian variabel mutasi terhadap kinerja karyawan diperoleh nilai beta $(\beta)$ sebesar 0,012 dengan $p$-value sebesar 0,907 . Karena nilai $p$-value lebih besar dari pada 0,05 atau $\alpha(0,907>0,05)$ maka $\mathrm{H}_{0}$ diterima. Dengan demikian dapat diambil kesimpulan bahwa mutasi mempunyai pengaruh yang negatif dan tidak signifikan terhadap kinerja karyawan Bank Mumalat Indonesia, Tbk cabang Jember.

6) H6(Pengaruh Variabel Demosi $\left(X_{3}\right)$ Terhadap Kinerja Karyawan $(Y)$ )

Berdasarkan tabel (uji Analisis Jalur) dapat dilihat untuk pengujian variabel demosi terhadap kinerja karyawan diperoleh nilai beta $(\beta)$ sebesar $-0,038$ dengan $p$-value sebesar 0,724 . Karena nilai $p$-value lebih besar dari pada 0,05 atau $\alpha(0,0724>$ $0,05)$ maka $\mathrm{H}_{0}$ diterima. Dengan demikian dapat diambil kesimpulan bahwa demosi mempunyai pengaruh yang negatif dan tidak signifikan terhadap kinerja karyawan Bank Mumalat Indonesia, Tbk cabang Jember.

7) H7(Pengaruh Variabel Motivasi (Z) Terhadap Kinerja Karyawan (Y)) Berdasarkan tabel (uji Analisis Jalur) dapat dilihat untuk pengujian variabel motivasi terhadap kinerja karyawan diperoleh nilai beta $(\beta)$ sebesar 0,685 dengan $p$ - 
valuesebesar 0,000 . Karena nilai $p$-value lebih kecil dari pada 0,05 atau $\alpha(0,000<$ $0,05)$ maka $\mathrm{H}_{0}$ ditolak. Dengan demikian dapat diambil kesimpulan bahwa motivasi mempunyai pengaruh yang positif dan signifikan terhadap kinerja karyawan Bank Muamalat Indonesia, Tbk cabang Jember.

Analisis Jalur (Path Analysis).

Bagian ini menguraikan signifikansi tiap-tiap jalur dalam model dengan menggunakan analisis jalur. Tiap-tiap jalur yang diuji menunjukkan adanya pengaruh langsung dan tidak langsung promosi, mutasi, dan demosi terhadap motivasi dan kinerja karyawan. Apabila terdapat jalur yang tidak signifikan, maka jalur tersebut akan dihilangkan dengan ketentuan trimming theory. Model analisis jalur disajikan pada gambar 1 berikut:

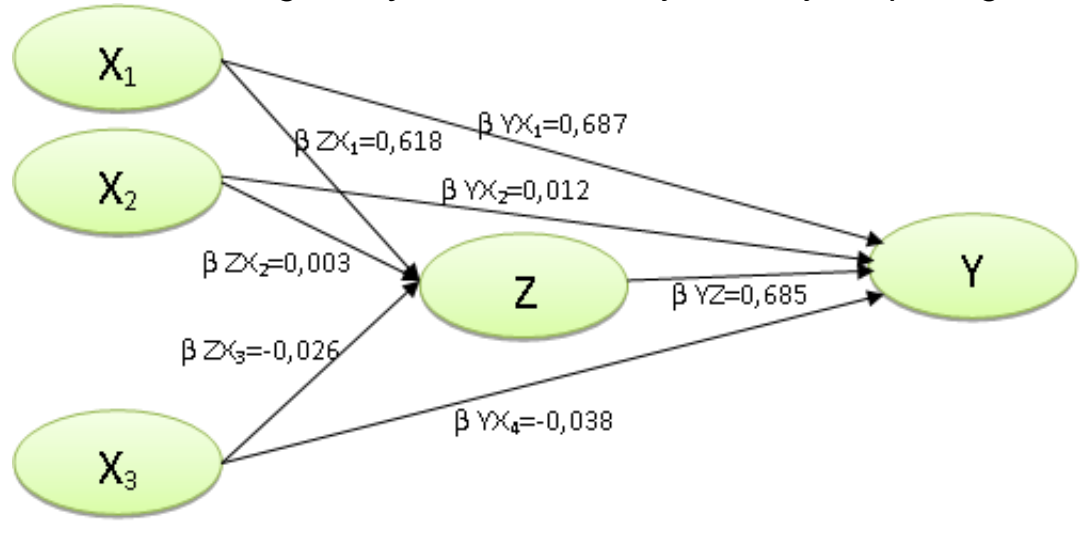

Gambar 1: Analisis Jalursumber: data primer diolah

Dari gambar 1 dapat diketahui persamaan jalur struktural sebagai berikut :

$Z=b_{0}+0,618 X_{1} Z+0,003 X_{2} Z-0,026 X_{3} Z+\varepsilon_{1}$ ...(persamaan 1)

$Y=b_{0}+0,687 X_{1} Y+0,012 X_{2} Y-0,038 X_{3} Y+0,362 Z Y+\varepsilon_{2} \ldots . .($ persamaan 2$)$

\section{Trimming Theory}

Berdasarkan hasil analisis pada jalur 1, nilai t-hitung pada uji t yaitu pengujian koefisien regresi variabel dibakukan secara parsial dengan nilai masing-masing variabel promosi sebesar 3,362, variabel mutasi jabatan sebesar 0,014, dan demosi jabatan sebesar $-0,125$. Sedangkan pada jalur 2 nilai t-hitung masing-masing menunjukkan nilai sebesar 7,098 untuk variabael promosi, 0,118 variabel mutasi, $-0,357$ variabel demosi, dan 8,641 untuk variabel motivasi. Selain itu, nilai $p$ value sebuah model dikatakan signifikan apabila nilai $p$ value $<0,05$. Pada jalur 1 nilai $p$ value variabel promosi sebesar 0,002 , mutasi sebesar 0,989 , dan demosi jabatan sebesar 0,902 . Sedangkan pada jalur $2 \mathrm{p}$-valuevariabel promosi sebesar 0,000 , mutasi sebesar 0,907 , demosi jabatan sebesar 0,724 dan motivasi kerja sebesar 0,000 .

Hasil ini menunujukkan bahwa pada jalur pertama, variabel promosi berpengaruh positif dan signifikan terhadap motivasi kerja. Sedangkan dua variabel lainnya yakni mutasi jabatan dan demosi jabatan tidak berpengaruh positif dan signifikan terhadap motivasi kerja. 
Hasil ini juga menunjukkan bahwa pada jalur kedua terdapat dua variabel independen yakni variabel promosi dan motivasi kerja yang memiliki pengaruh positif dan signifikan terhadap kinerja karyawan. Sedangkan dua variabel lain yakni mutasi jabatan dan demosi jabatan tidak berpengaruh positif dan signifikan terhadap kinerja karyawan.

Hasil Perhitungan Analisis Jalur

Berdasarkan hasil perhitungan koefisien jalur, dapat diketahui pengaruh langsung (direct effect) dan tidak langsung (indirect effect) maupun pengaruh totalnya (total effect).

1) Pengaruh variabel Promosi Jabatan $\left(X_{1}\right)$ terhadap Kinerja Karyawan $(Y)$ melalui Motivasi Kerja (Z)

$$
\begin{aligned}
& \operatorname{IEyzx}_{1}=X_{1} \rightarrow Z \rightarrow Y \\
& \text { IEyzx }_{1}=(0,618 \times 0,685)+0,423=0,846
\end{aligned}
$$

2) Pengaruh variabel Promosi Jabatan $\left(X_{1}\right)$ terhadap Kinerja Karyawan $(Y)$ melalui Motivasi Kerja (Z)

$\mathrm{IEy}_{2} \mathrm{y}_{1} \mathrm{x}_{2}=\mathrm{X}_{2} \quad \rightarrow \mathrm{Y}_{1} \rightarrow \mathrm{Y}_{2}$

$I E y_{2} y_{1} x_{2}=(0,003 X 0,685)+0,002=0,004$

3) Pengaruh variabel Promosi Jabatan $\left(X_{1}\right)$ terhadap Kinerja Karyawan $(Y)$ melalui Motivasi Kerja (Z)

$$
\begin{aligned}
& \text { IEy } \mathrm{y}_{2} \mathrm{y}_{1} \mathrm{x}_{3}=\mathrm{X}_{3} \quad \rightarrow \mathrm{Y}_{1} \rightarrow \mathrm{Y}_{2} \\
& \mid E y_{2} y_{1} x_{3}=(-0,026 \times 0,685)+0,017=0,034
\end{aligned}
$$

\section{Pengaruh Promosi $\left(\mathrm{X}_{1}\right)$ terhadap Motivasi $(\mathrm{Z})$}

Berdasarkan hasil uji hipotesis, menunjukkan bahwa Variabel Promosi Jabatan yang terdiri dari 3 indikator yakni tanggung jawab tambahan, kenaikan jabatan dan peningkatan penghasilan berpengaruh positif dan signifikan terhadap Motivasi Kerja pada Karyawan PT Bank Muamalat, Tbk cabang Jember. Hal ini menunjukkan bahwa semakin tinggi program promosi jabatan yang diberikan, maka akan meningkatkan motivasi karyawan dalam bekerja. Demikian juga sebaliknya, rendahnya program promosi jabatan yang diberikan perusahaan akan berdampak pada rendahnya motivasi karyawan untuk bekerja. yang menyatakan bahwa promosi jabatan berpengaruh signifikan terhadap motivasi kerja karyawan.

Bank Muamalat Indonesia, Tbk cabang Jember untuk membangun budaya kerja yang kompetitif diantara karyawannya tentu saja telah menerapkan program promosi jabatan. Hasil penelitian menunjukkan pengaruh yang positif dan signifikan variabel promosi jabatan terhadap motivasi kerja.Hal ini menunjukkan bahwa program promosi jabatan yang sudah terlaksana dengan baik. 


\section{$\underline{\text { Pengaruh Mutasi }\left(\mathrm{X}_{2}\right) \text { terhadap Motivasi }(\mathrm{Z})}$}

Berdasarkan hasil uji hipotesis, menunjukkan bahwa Variabel Mutasi Jabatantidakberpengaruh positif dan signifikan terhadap Motivasi Kerja pada Karyawa PT Bank Muamalat, Tbk cabang Jember. Hal ini berarti bahwa ada atau tidaknya program mutasi jabatan yang diberikan perusahaan pada karyawannya tidak akan meningkatkan motivasi karyawan untuk bekerja.

Hasil penelitian ini tidak mendukung teori yang diungkapkan oleh Siagian (1991:172) yang menyatakan bahwa adanya program mutasi berdampak pada motivasi dan kepuasan kerja karyawan yang lebih tinggi berkat tantangan dan situasi baru yang dihadapi. Hasil penelitian yang menyatakan bahwa tidak terdapat pengaruh variabel mutasi terhadap motivasi kerja menuntut perusahaan untuk mengkaji ulang program-program mutasi yang telah dilakukan.Program mutasi yang telah dilakukan mungkin saja tidak tepat sasaran untuk karyawan yang diberikan mutasi. Hal ini dikarenakan karyawan yang mendapatkan mutasi akan mendapatkan penghasilan yang relatif sama dengan gaji sebelumnya walaupun mereka mendapatkan pekerjaan atau tugas yang baru. Sehingga karyawan enggan untuk melaksanakan program mutasi.

\section{Pengaruh Demosi $\left(\mathrm{X}_{2}\right)$ terhadap Motivasi $(Z)$}

Berdasarkan hasil uji hipotesis, menunjukkan bahwa Variabel Demosi tidak berpengaruh positif dan signifikan terhadap Motivasi Kerja pada Karyawan PT Bank Muamalat, Tbk cabang Jember. Hal ini menunjukkan bahwa semakin banyak karyawan yang mendapatkan demosi jabatan maka motivasi mereka untuk bekerja tidak akan meningkat.

Hasil penelitian ini tidak mendukung teori yang diungkapkan oleh Siagian (2011:172) yang menyatakan bahwa demosi merupakan suatu bentuk pemberian motivasi negatif untuk memperbaiki perilaku karyawan yang memiliki perilaku disfungsional.

Hasil penelitian menyebutkan tidak terdapat pengaruh yang signifikan variabel demosi terhadap motivasi kerja.Hal ini mengindikasikan bahwa mayoritas karyawan kurang berkenan jika dirinya mendapatkan demosi jabatan dari perusahaannya. Karyawan yang mendapatkan demosi jabatan mungkin saja akan mengalami gangguan psikologis mereka, karena demosi dipandang sebagai devaluasi dari nilai personal. Sehingga hal ini akan menurunkan motivasi kerja yang ditandai dengan penurunan semangat dan kedisiplinan karyawan untuk bekerja.

\section{Pengaruh Promosi $\left(\mathrm{X}_{1}\right)$ terhadap Kineria Karyawan $(\mathrm{Y})$}

Berdasarkan hasil uji hipotesis, menunjukkan bahwa Variabel Promosi Jabatan berpengaruh positif dan signifikan terhadap kinerja pada Karyawa PT Bank Muamalat, Tbk cabang Jember. Hal ini menunjukkan bahwa semakin tinggi program promosi jabatan yang 
diberikan yang meliputi: pemberian tanggung jawab tambahan, pemberian kenaikan jabatan dan peningkatan penghasilan karyawan, maka hal ini dapat meningkatkan kinerja karyawan. Demikian juga sebaliknya, rendahnya program promosi jabatan yang diberikan perusahaan akan berdampak pada rendahnya kinerja pada Karyawan.

Hasil penelitian ini mendukung teori yang dikemukakan oleh Nitisemito (2001:109) yang menyebutkan bahwa salah satu faktor yang dapat mempengaruhi kinerja karyawan adala pemberian pelatihan dan promosi jabatan.Pada pembahasan sebelumnya menyebutkan bahwa promosi jabatan berpengaruh positif dan signifikan terhadap motivasi kerja.Dan pada hasil penelitian ini, nampaknya promosi jabatan secara konsisten juga mempengaruhi terhadap kinerja karyawan. Hal ini menunjukkan bahwa manajemen telah berhasil menerapkan program promosi dengan tujuan untuk meningkatkan kinerja karyawannya.

\section{Pengaruh Mutasi $\left(\mathrm{X}_{2}\right)$ terhadap Kinerja Karyawan $(\mathrm{Y})$}

Berdasarkan hasil uji hipotesis, menunjukkan bahwa Variabel Mutasi Jabatan tidak berpengaruh positif dan signifikan terhadap Motivasi Kerja pada Karyawa PT Bank Muamalat, Tbk cabang Jember. Hal ini berarti bahwa ada atau tidaknya program mutasi jabatan yang diberikan perusahaan pada karyawannya seperti: perpindahan karyawan dengan tugas yang baru, jabatan yang relatif sama, penghasilan yang relatif sama dan perpindahan lokasi tempat yang berbeda dengan sebelumnya tidak dapat meningkatkan motivasi karyawan untuk bekerja.

Hasil penelitian ini tidak sejalan dengan temuan dalam penelitian yang dilakukan oleh Herdianto (2013), yang menyatakan bahwa mutasi jabatan berpengaruh positif terhadap Kinerja karyawan, hal ini mengindikasikan bahwa mutasi jabatan yang diberikan pada karyawannya tidak dapat dilaksanakan dengan baik oleh karyawan, sehingga kinerja karyawan semakin menurun. Hasil ini juga menunjukkan bahwa karyawan PT Bank Muamalat, Tbk cabang Jember dalam melakukan pekerjaan dengan beban tugas baru tidak dapat diandalkan dengan kata lain program mutasi jabatan belum berjalan sesuai dengan tujuan perusahaan.

\section{Pengaruh $\left(\mathrm{X}_{3}\right)$ terhadap Kinerja Karyawan $(\mathrm{Y})$}

Berdasarkan hasil uji hipotesis, menunjukkan bahwa Variabel Demosi Jabatan tidak berpengaruh positif dan signifikan terhadap kinerja karyawan PT Bank Muamalat, Tbk cabang Jember. Hal ini menunjukkan bahwa semakin banyak karyawan yang mendapatkan demosi jabatan dalam hal ini mendapatkan penurunan tanggung jawab, penurunan jabatan dan penurunan penghasilan maka motivasi mereka untuk bekerja tidak akan meningkat.

Hasil penelitian ini tidak sejalan dengan hasil temuan Pratitha dkk (2012) yang menyatakan bahwa demosi jabatan berpengaruh positif dan signifikan terhadap kinerja 
karyawan.Pada hipotesis ketiga dalam penelitian ini, sebelumnya sudah menyatakan bahwa demosi jabatan tidak berpengaruh positif terhadap motivasi kerja.Hasil analisis nampaknya menunjukkan arah pengaruh yang konsisten antara demosi jabatan terhadap kinerja karyawan.Program demosi jabatan tidak berdampak pada peningkatan kinerja karyawan PT Bank Muamalat, Tbk cabang Jember.

\section{Pengaruh Motivasi( $Z$ ) terhadap Kinerja Karyawan $(Y)$}

Berdasarkan hasil uji hipotesis, menunjukkan bahwa variabel motivasi kerja berpengaruh positif dan signifikan terhadap kinerja pada Karyawa PT Bank Muamalat, Tbk cabang Jember. Hal ini menunjukkan bahwa semakin tinggi program motivasi yang diberikan oelh perusahaan maka akan semakin meningkatkan kinerja karyawan. Demikian juga sebaliknya, rendahnya program motivasi yang diberikan perusahaan akan berdampak pada penurunan kinerja pada Karyawan.

Hasil penelitian ini mendukung teori yang dikemukakan oleh Robbins (2003:224) yang mengatakan bahwa salah satu factor yang dapat mempengaruhi kinerja adalah pemberian motivasi pada karyawan.Manajemen dapat dinilai memberikan motivasi dengan baik terhadap karyawannya, hal ini dapat dilihat dari besaranya pengaruh motivasi kerja terhadap kinerja karyawan, yakni sebesar 68,5\%. Untuk itu perusahaan perlu mempertahankan dan meningkatkan upaya untuk mendorong karyawan agar dapat bekerja dengan tekun.

\section{Kesimpulan}

1. Kebijakan promosi karyawan Bank Muamalat Indonesia, Tbk cabang Jember berpengaruh positif dan signifikan terhadap Motivasi Kerja.

2. Kebijakan mutasi karyawan Bank Muamalat Indonesia, Tbk cabang Jember tidak berpengaruh positif dan signifikan terhadap Motivasi Kerja pada Karyawan PT Bank Muamalat, Tbk cabang Jember

3. Kebijakan demosi yang dilakukan oleh manajemen kepada karyawan Bank Muamalat Indonesia, Tbk cabang Jember tidak berpengaruh positif dan signifikan terhadap motivasi kerja.

4. Kebijakan promosi karyawan berpengaruh positif dan signifikan terhadap kinerja karyawan PT Bank Muamalat cabang Jember.

5. Kebijakan mutasi karyawan Bank Muamalat Indonesia, Tbk cabang Jember tidak berpengaruh positif dan signifikan terhadap kinerja karyawan PT Bank Muamalat, Tbk cabang Jember.

6. Kebijakan demosi yang dilakukan oleh manajemen kepada karyawan Bank Muamalat Indonesia, Tbk cabang Jember tidak berpengaruh positif dan signifikan terhadap kinerja karyawan PT Bank Muamalat, Tbk cabang Jember. 
7. Motivasi kerja berpengaruh positif dan signifikan terhadap kinerja pada Karyawan PT Bank Muamalat, Tbk cabang Jember.

Berdasarkan kesimpulan diatas menunjukkan ada beberapa pengaruh variabel yang tidak signifikan, sehingga dilakukan trimming theory dengan menghilangkan pengaruh variabel mutasi $\left(\mathrm{X}_{2}\right)$ dan demosi $\left(\mathrm{X}_{3}\right)$ terhadap motivasi $(\mathrm{Z})$ dan variabel mutasi $\left(\mathrm{X}_{2}\right)$ demosi $\left(\mathrm{X}_{3}\right)$ terhadap kinerja karyawan $(\mathrm{Y})$.

\section{Saran}

1. Perlu kesadaran karyawan dalam memotivasi diri untuk lebih mampu beradaptasi dengan kondisi yang baru, khususnya kebijakan penempatan karyawan. Berusaha untuk selalu mengambangkan diri dan berpikir maju. Harapannya adalah dapat tercapainya kinerja karyawan yang optimaal yang dapat bermanfaat bagi diri sendiri dan manajemen.

2. Pimpinan harus mempertimbangkan faktor-faktor dalam penentuan penempatan kerja karyawan, faktor dari promosi, mutasi, dan dem osi. Program ini tetap dijalankan dengan pertimbangan yang cermat dan teliti agar berdampak positif, sehingga nilai-nilai positif atas pelaksanaan program promosi dan mutasi nampak pada perusahaan dan karyawan itu sendiri.

3. Membuat kebijakan baru terkait dengan penenpatan kerja (promosi dan mutasi) sebagai syarat untuk kenaikan grade. Hal ini nantinya akan berdampak termotivasinya karyawan untuk pengembangan diri, bersemangat memiliki kemampuan di bidang lain dan memperdalam bagian lainnya.

4. Memotivasi karyawan untuk selalu berupaya mengembangkan diri dan melakukan uji secara berkala terkait dengan kemampuan karyawan pada suatu bidang.

5. Perlu kajian lanjutan terhadap variabel-variabel lainnya yang dapat mempengaruhi kinerja karyawan, sehingga nantinyadapat ditemukan variabel yang pas dalam meningkatkan kinerja karyawan.

\section{Daftar Referensi}

Herdianto, Fendy. 2013. Pengaruh Good Corporate Governance terhadap tingkat profitabilitas bank umum syariah di Indonesia. Skripsi. Fakultas Ekonomi Universitas Negeri Malang, Malang

Hasibuan, H. Melayu S P. 2002. Manajemen Sumber Daya Manusia. Jakarta:Gunung Agung.

Nitisemito, Alex, S,. 2001. Manajemen Personalia (Manajemen Sumber Daya Manusia, Edisi Kelima, Cetakan Keempat belas. Jakarta: Ghalia Indonesia.

Pratita, N. D. (2012). Hubungan dukungan pasangan dan health locus of Control dengan kepatuhan dalam menjalani proses pengobatan pada penderita diabetes mellitus tipe 2 . Jurnal IImiah Mahasiswa Universitas Surabaya, Vol.1 No.1 
Robbins, Stephens P., 2003, Perilaku Organisasi, Edisi Kesepuluh, Prentice-Hall, Jakarta

Siagian, P. Sondang. 1991.Manajemen Sumber Daya Manusia. Jakarta: Bumi Aksara. 